\title{
Science-related aspirations of career based on learning content in upper secondary level
}

\author{
Mohd Razimi Husin ${ }^{1}$, Hishamuddin Bin Ahmad ${ }^{2}$, Muhammad Bazlan Bin Mustafa ${ }^{3}$, \\ Ismail Yusuf Panessai ${ }^{4}$, Ramlan ${ }^{5}$ \\ 1,2,3,4 Universiti Pendidikan Sultan Idris, Malaysia \\ ${ }^{5}$ Universitas Pasundan, Indonesia
}

\begin{tabular}{l} 
Article Info \\
\hline Article history: \\
Received Apr 7, 2020 \\
Revised Sep 20, 2020 \\
Accepted Oct 21, 2020 \\
\hline
\end{tabular}

\section{Keywords:}

Career aspiration

Science subject

Secondary students

Teaching and learning

\begin{abstract}
This study used qualitative approach which involves interviews that are analyze using Nvivo software. Qualitative approach which uses phenomenological design to reflect on the experience of the former students towards their experience and learning contents of secondary school upper level science core subject which impacted their career aspirations today. Twelve experience workers were selected through purposeful sampling. The results show that most respondent just got $\mathrm{C}$ for their Science Subject in Malaysian Certificate of Education (MCE). The certain techniques including the use of the learning aids and room were very effective; while contents of fluid and organs were much related to works. This study has revealed the effective techniques of learning experiences that beneficial to all educators.
\end{abstract}

This is an open access article under the CC BY-SA license.

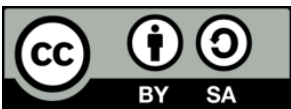

Corresponding Author:

Mohd Razimi Husin,

Department of Educational Psychology,

Universiti Pendidikan Sultan Idris,

35900 Tanjung Malim, Perak, Malaysia.

Email: razimi@fpm.upsi.edu.my

\section{INTRODUCTION}

The implementation of teaching and learning which emphasize on the effective learning experiences and effective learning content in their daily life and the future of students' work is very important. Aspects of the effective learning experiences and effective learning content that taking into account student career aspirations are necessary to meet the findings of study that is learning to meet the requirements of their employers [1]. The kind of learning are taking into account of having a chosen career for future profession, having a sense of care, aware of the characteristics of their choice of career and confident in their ability to perform their chosen career [1]. However, there is no specific research for teaches for it to be use as a guide. The new curriculum implemented addresses the content that is required to be delivered to the students based on their core and stream of the students [2]. One of the subjects that SPM students must take is Science. According to Tripney, et al. [3], improvement in the education system in science is a key element in strengthening Science education. This requires a strategic framework to support the science and future careers of students [4]. Tripney, et al. suggest that adolescents make career choices at the next school level. Based on past studies of effective Science learning experiences, it is through hands-on methods [5-7]. In addition to methods of hands-on activity simulation and games are methods that enhance students' understanding of Science subjects $[8,9]$. Collaborative and problem-solving activities also help students understand the content of Science subjects [10]. Other studies have found teamwork, responsibility, and collaborative learning appears to be the most important factors for effective learning [11-14]. 
It is the greater responsibility of all teachers to implement the content knowledge in the most beneficial manner to the students [15]. The willingness to do something beneficial and implementing the appropriate improvements will enhance the quality of knowledge presented, organizations and communities and countries towards excellence. A person's knowledge and skills begin at school through the lesson at school. "Enabling active participation, using different methods and techniques, enabling meaningful learning, class management, and directing to different resources" were not present at the beginning of the program [15]. Out-of-class activities created and associated with past historical events help students easily receive information, and similarly, this approach gives students confidence to present learning content after a discussion session with peers [16].

Students are taught to follow their chosen stream which they selected after form three. However, the chosen stream may not necessarily build a career aspiration in their soul [17]. Some of them want to work in an area that is less relevant to their chosen stream. Students will learn something meaningfully if they are able to make their knowledge gained in school as aspirations for their future live and occupations as well as the objectives of Kurikulum Bersepadu Sekolah Menengah (Secondary School Integrated Curriculum) and Kurikulum Standard Sekolah Menengah (Secondary School Standard Curriculum) [18]. The approach and method used by the teacher is a key support tool that helps to improve the students' understanding of their daily needs and careers. Therefore, in-depth research is needed not only on the students' knowledge, but also approaches and strategies that contributes to the aspirations of the students' careers in content delivery. This research selected science subject as a study's set because it is a core subject for the humanities stream students. In addition, appropriate learning experiences and content are expected to help the students not only achieving a high performance in science subjects, but a have stronger career aspirations.

Teenage students are found to not have a career of choice at the beginning. According to Gutman and Schoon [19], there are teenagers with uncertain career aspirations to have high academic performance at the age of 16. Likewise, teenagers who have a low performance are likely to have uncertain career aspirations [20]. The objective of the Ministry of Education (MOE) in the Curriculum Specifications still hopes that the knowledge gained by the students from the outset will assist them in their daily life and career selection. One the step taken by MOE is to apply skills for the teenager at the early stage as done in the Vocational College Curriculum. However, the stream of upper secondary level educations in the MOE secondary school whether it is science, humanity or accounting is not a determinant of career selection. Previous research related to the accounting stream students found that experience and the content of learning in accounting did not help in the student's career selection in their respected stream. According to Zainal, Suhaida and Zaidatol [21] accounting stream students do not necessarily want to work in the accounting field. Therefore, this research does not only look on the factors of subject, but rather on the experience and the learning content that should be used in the classroom.

The findings confirmed that education aspirations are one of the factors in understanding career aspirations among the younger generations $[22,23]$. As such, the educational aspiration presented in the $21^{\text {st }}$ century learning has become one of the aims of this research to look at the needs of the national education aspiration. Each learning content has its own importance in everyday life. However, implementing the right strategy will determine its effectiveness [24]. Science is an important core subject for humanity stream students and $80 \%$ of the upper secondary school students will take this subject. Therefore, the experience and the learning content of the science subject have to be emphasized due to its reason to be one of the important subjects which will indirectly affects the student's career aspirations.

Individual learning content and experience are inadequate if they are only able to apply what they have learned while disregarding its needs in daily life or future use [25]. The same goes for the learning for the sake of passing an examination. The $21^{\text {st }}$ century education emphasizes on learning for life [26]. Therefore, educational body have to investigate deeper regarding this issue. Not only do technical stream and vocational stream student have to be paid special attention in the aspect of career, but experience and learning content of mainstream school have to be look at on the aspect of learning for life. As such, this research will look at the experience and science learning content which are related to the daily life and career aspirations as well as other aspects which are related to the former Sijil Pelajaran Malaysia (SPM) students in their career selection. While, top management leadership was discovered to have the most significant relationship with job satisfaction [27]. Whereas those who got lower achievement in school for science core subject does not have future aspiration during school age. They work based on opportunity surround them.

This paper present learning and content experiences related to the students' achievement, the most effective approach to the medium level of students and learning experience and content that related to work in Science core subject. This study uses qualitative method in examining the effectiveness approach of the learning that in the subject and the related content to works. The study showed that most respondent just got $\mathrm{C}$ for their Science Subject in SPM, the certain techniques including the use of the learning aids and room were very effective and content of fluid and organs were much related to work. 


\section{RESEARCH METHOD}

This research used qualitative approach involving interviews and documentation analyzed using NVivo software. This research is a cross-sectional study involving former high school students over 10 years and below of finishing school and having their own careers. The qualitative approach in this research uses phenomenological design to describe students' experiences of the content of upper secondary learning for science as well as career aspirations related to the experience and content of learning in the subject. To measure the career aspirations of this research, participants were asked to answer open questions adapted from the career aspirations questions by Creed, et al. [28].

The qualitative approach in this study emphasizes interviews and documentation. In collecting and analyzing data, researchers will use coding, refining, categories and concepts linking and develop theories as suggested by Merriam [29]. The research participants were selected as intended in the study of Jaafar and Husin [30-33]. The information is processed by reduction or screening, coding and verification, and is analyzed based on themes performed according to the study participants. One of the strategies in this approach is to concentrate on information that may produce large amounts of data initially and remove the less important information as suggested by Miles and Huberman [34].

The interviews to be conducted are semi-structured whereby the questions draft are provided as guidelines and are conducted individually. Interview data will be transcribed into text form for easy data interpretation. Researchers interviewed 12 former Batang Padang and Kinta North secondary school students who took Science as their core subject. They were selected by purposive sampling to obtain clear information on one to three research questions. This research is a design that has the phenomenon that needed to be researched and the context of research [35]. Examples of the phenomena that are examined are the learning activities, titles and knowledge of form four and five that have a lot to do with their daily life and career aspirations, Science learning experiences that can develope personal interest in careers, the real factors of career selection for Sijil Pelajaran Malaysia (SPM) students.

\section{RESULTS}

Based on observations made on Science subjects to support the literature review, it shows that most students got medium level in their SPM achievement. There were several effective approaches to the medium level of students in Science core subject. Science core subject is related to work in learning experience and content. The extent to which these needs to everyday life and future work for students and further study on it need to be further discussed.

\subsection{Level of students' achievement in science core subject}

Information of students' achievement in SPM requires to takes into account to generalize the data in this study. The results were obtained through the documents of SPM result show by the respondents as shown in Table 1. Most students are not good in their SPM results. Most respondent just got C for their Science subject.

Table 1. Level of students' achievement in science core subject

\begin{tabular}{ccccccccccccc}
\hline & S1 & S2 & S3 & S4 & S5 & S6 & S7 & S8 & S9 & S10 & S11 & S12 \\
\hline Students achievement & C & D & C & C & C & C & C & C & C & C & C & C \\
\hline
\end{tabular}

\subsection{The most effective approach to the middle level students}

There are a number of sub-topics in Science upper secondary school subject that are appropriate for the certain approach to the middle level students. The approach is including the use of the real learning aids and practical in laboratory room such as shown in Table 2. Real learning aids are like frogs, while practicals in the lab are like mixing certain colors to produce new colors.

Table 2. The most effective approach to the middle level of students

\begin{tabular}{ccccccccccccc}
\hline Effective Approach & S1 & S2 & S3 & S4 & S5 & S6 & S7 & S8 & S9 & S10 & S11 & S12 \\
\hline Laboratory & $/$ & $/$ & $/$ & $/$ & $/$ & $/$ & $/$ & $/$ & $/$ & $/$ & $/$ & $/$ \\
Real Learning aid & $/$ & $/$ & $/$ & $/$ & $/$ & $/$ & $/$ & $/$ & $/$ & $/$ & $/$ & $/$ \\
\hline
\end{tabular}




\subsection{Learning content that related to work}

However, for participants working at the airport, associating their current work with fluid elements, various fluids to aircraft, luggage should be monitored. While the internal organs such as the lungs, liver and intestines are highly health-related organs and serve a great role in promoting daily activities such as breathing, poaching and body toxins according to information provided by the study participants:

Teachers bring things, like puppets, hearts, bowels, he shows them all to us ... come to think of it. There must be some connection there between organ and our job. Organ works for all human life including work.

As well the nerves, it means that when we do all work, our nerves work. But it has nothing to do with our skills as a salesperson. But for freight loader workers, it is related to the musle and how to properly load the goods. This study showed that there were a few jobs that related to the Science core subject but still given the basic knowledge and need further skills such as motorcycle mechanic beside freight loader and salesperson as shown in Figure 1. They had no idea of their future job during the past form 4 and form 5 . Table 3 shows the contents that related to the jobs that is fluid and organs; whereas, the Bunsen burner is matching for motorcycle mechanics only.

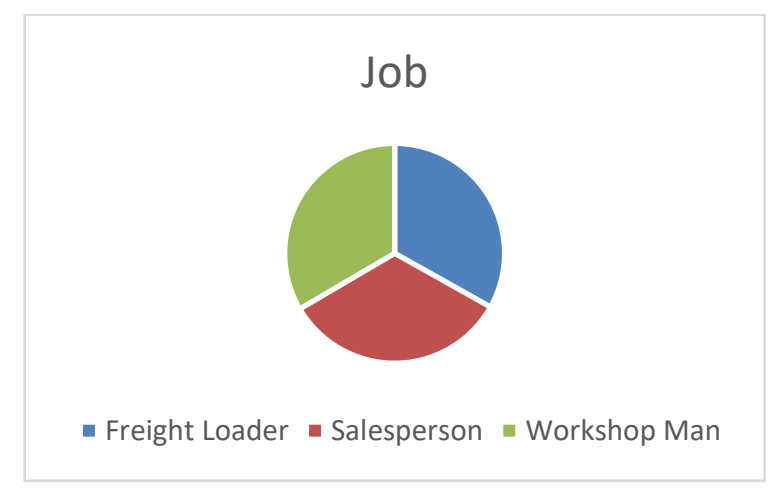

Figure 1. Related jobs to the science core subject

Table 3. Learning content that related to work

\begin{tabular}{ccccccccccccc}
\hline Contents & S1 & S2 & S3 & S4 & S5 & S6 & S7 & S8 & S9 & S10 & S11 & S12 \\
\hline Fluid & $/$ & $/$ & $/$ & $/$ & $/$ & $/$ & $/$ & $/$ & $/$ & $/$ & $/$ & $/$ \\
Organs & $/$ & $/$ & $/$ & $/$ & $/$ & $/$ & $/$ & $/$ & $/$ & $/$ & $/$ & $/$ \\
\hline
\end{tabular}

\section{DISCUSSION}

The responsibility of teachers is very much needed to teach middle class students because most students are in this circle [36]. The effective approaches to the medium level of students in Science core subject are regulating the use of laboratories, organizing them with tactical activities and appreciating using the organ learning tools. Fluid and organs are the most learning content that related to work. Teachers should have an ideal way to teach students how to use self-monitoring strategies such as a study that focuses on the importance of monitoring and self-efficacy strategies that help students practice them [37]. Teaching in the classroom should relate to daily life or the outside actual situation including at workplace. In science, there are many syllables that can be directly related to work. Examples of jobs related to science and everyday life is nursing [38].

Although student achievement is fair in science core subject, the long-term impact is important so that the knowledge gained in school can be leveraged later. It will expect that education will become more meaningful and national education institutions will excel in such a way of learning. The fact in science should not be a tentative but inspire student to think of career. It is understood that all science information is tentative and can be evolving. It is the role of teachers to keep students' experiential to develop meaningful contextual information. Teachers and researchers should not be shy about saying or doing so, both to those in schools and to those in charge of schools [39]. Teachers also need to move from the old-fashioned approach to pressures appropriate to $21 \mathrm{st}$ century education. Previous study was shown that top management leadership that had career aspiration as early as in school age, but the ex-students with lower achievement 
and did not have future aspiration was discovered to have the uncertainty in their career. In a nut shell, what is valued in science subject is what is considered relevant in the student's context that influences their lives [40].

\section{CONCLUSION}

This paper presents science-related aspirations of career based on learning content in Upper Secondary Level. Core Science subject teachers should use the most appropriate approach to students. Such an approach is like using existing-real learning aids and doing practicals in the laboratory especially for topics that are much related to the daily routine of students and future prospects to students. According to previous studies, teachers should have appropriate methods to teach students how to use self-monitoring strategies. However, the level of students studied required more guidance from teachers than self-monitoring. In science, there are many syllabuses that are directly related to occupations such as nursing. But on the other hand, the core Science subject will not qualify students to venture into the field of nursing according to the qualifications of nurses in some universities.

\section{ACKNOWLEDGEMENTS}

This paper is based on the research project entitled Aspirasi Kerjaya Berasaskan Pengalaman dan Kandungan Pembelajaran Sains Pelajar Menengah Atas. The authors would like to extend their gratitude to the Research Management and Innovation Centre (RMIC), Sultan Idris Education University (UPSI) for the University Research Grant Based on Education (2019-0080-107-01) Phase 1/2019 that helped fund the research

\section{REFERENCES}

[1] R. Tladinyane and M. Merwe, "Career adaptability and employee engagement of adults employed in an insurance company: An exploratory study," SA Journal of Human Resource Management, vol. 14, no. 1, p. 752, 2016.

[2] R. Sampangi and A. Siegel, "Designing Engaging Learning Experiences," in Proceedings of the 2019 ACM Conference on Innovation and Technology in Computer Science Education (ITiCSE '19). Association for Computing Machinery, New York, USA, pp. 10-18, 2019.

[3] J. Tripney, et al., "Factors Influencing Young People (Aged 14-19) in Education about STEM Subject Choices: A Systematic Review of the UK Literature," Evidence for Policy and Practice Information and Co-Ordinating Centre, Institute of Education, University of London, London, 2010.

[4] J. Jufrida, et al., "The correlation between scientific literacy and science learning achievement at junior high School," International Journal of Evaluation and Research in Education (IJERE), vol. 8, no. 4, pp. 106-204, 2019.

[5] S. Peterson and S. Scott, "As part of the Improved Methods for Teaching Science," School Science Review, vol. 71, pp. 63-72, 2018.

[6] S. Walan, "Teaching children science through storytelling combined with hands-on activities - a successful instructional strategy?" International Journal of Primary, Elementary and Early Years Education, vol. 47, no. 1, pp. 34-46, 2017.

[7] R. Hubahib, "Students' Performance in Inquiry and Hands-On Activities on Eating and Exercis," Mancester City: MSU-Iligan Institute of Technology, 2016.

[8] N. Balasubramaniam, et al., "Innovative Methods of Teaching Science and Engineering in Secondary Schools," Systemics, Cybernetics And Informatics, vol. 6, no. 6, pp. 41-46, 2006.

[9] N. Chetty, et al., "Learning Styles and Teaching Styles Determine Students' Academic Performances," Journal of Evaluation and Research in Education (IJERE), vol. 8, no. 4, pp. 25-32, 2019.

[10] R. Zenda, "Essential teaching methods to enhance learner academic achievement in physical sciences in rural secondary schools: A South African case study," Information and Learning Sciences, vol. 118, no. 3/4, pp. 170-184, 2017.

[11] G. Crebert, et al., "Developing generic skills at university, during work placement and in employment: graduates' perceptions," Higher Education Research \& Development, vol. 23, no. 2, pp. 147-165, 2004.

[12] N. Wamba and K. Dunn, "Effective Individualized Educational Plans: Do Something Special with Learning Styles," Insights on Learning Disabilities, vol. 6, pp. 1-11, 2009.

[13] O. Goethe, "Learning Experiences in Real Life," in Gamification Mindset. Human-Computer Interaction Series. Springer, Cham, pp. 14-20, 2019.

[14] W. Widodo, "Assessing the Readiness of Student Learning Acitivity and Learning Outcome," Jurnal Pencerahan, vol. 10, pp. 81-94, Sep. 2016.

[15] M. Behrendt and T. Franklin, "A Review of Research on School Field Trips and Their Value in Education," International Journal of Environmental and Science Education, vol. 9, no. 3, pp 235-245, 2014. 
[16] Z. Ayvaz-Tuncel and İ. Tuncel, "Good teacher perceptions of students attending the pedagogical formation certificate program," International Journal of Evaluation and Research in Education (IJERE), vol. 8, no. 1, pp. 165-172, 2019.

[17] M. Husin, et al., "Inductive instructional approach, career aspiration and noble values in history," International Journal of Evaluation and Research in Education (IJERE), vol. 9, no. 1, pp. 162-167, 2020.

[18] T. Selvam, "Career Aspiration Among Rural Undergraduate Students," International Research Journal of Human Resources and Social Sciences, vol. 4, no. 12, pp. 21-27, 2017.

[19] Kementerian Pendidikan Malaysia, Dokumen standard kurikulum dan pentaksiran. Kuala Lumpur: Bahagian Pendidikan Guru, pp. 1-40, 2015.

[20] L. Gutman and I. Schoon, "Correlates and consequences of uncertainty in career aspirations: Gender differences among adolescents in England," Journal of Vocational Behavior, vol. 80, no. 3, pp. 608-618, 2012.

[21] Z. Ismail, et al., "Career Aspiration among Secondary School Accounting Students in Selangor," International Conference on Humanities, Society and Culture IPEDR, vol. 20, pp. 1-8, 2011.

[22] M. Gregor, et al., "Understanding Career Aspirations among Young Men," Journal of Career Assessment, vol. 27, no. 2, pp. 262-272, 2017.

[23] M. Gregor and K. O’Brien, “Understanding Career Aspirations among Young Women: Improving Instrumentation," Journal of Career Assessment, vol. 24, no. 3, pp. 559-572, 2015.

[24] M. Jony, "Exploring the Effectiveness of Cooperative Learning at Secondary Level in Bangladesh," International Journal of Educational Research Review, vol. 5, no. 1, pp. 93-99, 2019.

[25] O. Wijaya and I. Bukhori, "Effect of Learning Motivation, Family Factor, School Factor, and Community Factor on Student Learning Outcomes on Productive Subject," Jurnal Pendidikan Bisnis dan Manajemen, vol. 3, no. 3, pp. 192-202, 2017.

[26] B. Shola, et al, "The non-technical skills needed by graduates of technical colleges in metalwork technology for future Employment," International Journal of Evaluation and Research in Education (IJERE), vol. 8, no. 4, pp. 98-106. 2019.

[27] C. Ong, "Factors influencing job satisfaction among academic staffs: Evidence from Malaysia," International Journal of Evaluation and Research in Education (IJERE), vol. 9, no. 2, pp. 285-291, 2020.

[28] P. Creed, et al., "The relationship between goal orientation and career striving in young adolescents," Journal of Applied Social Psychology, vol. 43, no. 7, pp. 1480-1490, 2013.

[29] S. Merriam, Qualitative research and Case Study Applications in Education. San Francisco: Jossey-Bass Pub., 2001.

[30] M. Husin, et al., "Gaya Pembelajaran dan Persekitaran yang Mempengaruhi Murid Sukar Belajar Dalam Mata Pelajaran Pendidikan Islam,” Jurnal Penyelidikan Dedikasi, vol 11, pp. 98-111, 2011.

[31] M. Husin, "Exploring the Use of Digital Devices among Pupils with Learning Disabilities," International Journal of Multimedia and its Applications, vol. 9, no. 4/5/6, pp. 75-86, 2017.

[32] M. Husin, et al., "Video Application Model in Learning Styles of Moral Education Students in Teacher Educational Institution," International Journal of Engineering and Technology (UAE), vol. 7, no. 4, pp. 21-26, 2018.

[33] M. Husin, et al., "Making Short Video and Multi-Sensory Instructional Packages for Moral Education Courses in Teacher Education Institutes," Global Journal of Advanced Engineering Technologies and Sciences, vol. 5, no. 12, pp. 9-18, 2018.

[34] M. Miles and M. Huberman, Qualitative data analysis: A source book for new methods. Beverly Hills, CA: Sage Publications, pp. 35-50, 1984.

[35] N. Idris, Penyelidikan dalam pendidikan. Kuala Lumpur: McGraw Hill, pp. 45-52, 2010.

[36] M. Barros, "Teachers' responsibility in the education of medium-level personnel," Revista brasileira de enfermagem, vol. 38, no. 1, pp. 95-100, 1985.

[37] R. Ueki, "Ideal Ways to Teach Students How to Utilize Self-Monitoring Strategies," Japanese Journal of Educational Psychology, vol. 52, no. 3, pp. 277-286, 2013.

[38] K. Tsuda, "Nursing related to daily life," Kango kyoshitsu (Nursing classroom), vol. 18, no. 5, pp. 14-15, 1974.

[39] Editors, "School daze: As US states turn the screw on science education, researchers everywhere should pay more attention to how their subject is presented," Nature, vol. 543, p. 149, 2017.

[40] L. Franco and Danusa Munford, "Science learning: an analysis of discursive interactions and different spacetemporal dimensions in the classroom daily life," Brasileira de Educação, vol. 25, no. 1, pp. 1-31, 2020. 